\title{
Interspecific variation of heavy metal concentrations in the different parts of tropical intertidal bivalves.
}

\begin{abstract}
The concentrations of $\mathrm{Cd}, \mathrm{Cu}, \mathrm{Fe}, \mathrm{Ni}, \mathrm{Pb}$ and $\mathrm{Zn}$ in the different parts of six bivalves species were determined. From the study conducted, it was found that the byssus of Perna viridis, Scpharca broughtonii and Trisidos kiyonoi; the gill of Polymesoda erosa and Donax faba; and the foot of Gelonia expansa were highly accumulative of $\mathrm{Cu}$. High levels of $\mathrm{Cd}$ were found in the gills of Scpharca broughtonii and the byssus of Trisidos kiyonoi; and also the shells of the four remaining bivalve species. As for $\mathrm{Zn}$, the mantles of $\mathrm{P}$. erosa and $\mathrm{T}$. kiyonoi, and the gills of D. faba, G. expansa and S. broughtonii were highly accumulative of Zn. High level of $\mathrm{Pb}$ and $\mathrm{Ni}$ were found in the shells of all the species which indicated that the shells of the bivalves were highly accumulative of $\mathrm{Pb}$ and $\mathrm{Ni}$. Elevated levels of $\mathrm{Fe}$ however were found in the different parts of the bivalve since Fe is an essential metal in metabolic activities and an abundant element in nature. The heavy metals in the total tissues and the different soft tissues of the bivalves were compared with the maximum permissible limits set by five different countries. From the comparison, it was found that most of the bivalves contained metal concentrations which were below the maximum permissible limits and should pose no toxicological risk to consumers.
\end{abstract}

Keyword: Heavy metal; Different parts; Bivalves; Malaysian coast; Bioavailabilities; Contamination 